IZA DP No. 6673

Peer Salaries and Employee Satisfaction in the Workplace

Karen Mumford

Peter N. Smith

June 2012 


\title{
Peer Salaries and Employee Satisfaction in the Workplace
}

\author{
Karen Mumford \\ University of York \\ and IZA
}

\section{Peter N. Smith}

University of York

\section{Discussion Paper No. 6673 \\ June 2012}

IZA
P.O. Box 7240
53072 Bonn
Germany

\author{
Phone: +49-228-3894-0 \\ Fax: +49-228-3894-180 \\ E-mail: iza@iza.org
}

\begin{abstract}
Any opinions expressed here are those of the author(s) and not those of IZA. Research published in this series may include views on policy, but the institute itself takes no institutional policy positions.

The Institute for the Study of Labor (IZA) in Bonn is a local and virtual international research center and a place of communication between science, politics and business. IZA is an independent nonprofit organization supported by Deutsche Post Foundation. The center is associated with the University of Bonn and offers a stimulating research environment through its international network, workshops and conferences, data service, project support, research visits and doctoral program. IZA engages in (i) original and internationally competitive research in all fields of labor economics, (ii) development of policy concepts, and (iii) dissemination of research results and concepts to the interested public.
\end{abstract}

IZA Discussion Papers often represent preliminary work and are circulated to encourage discussion. Citation of such a paper should account for its provisional character. A revised version may be available directly from the author. 
IZA Discussion Paper No. 6673

June 2012

\begin{abstract}

\section{Peer Salaries and Employee Satisfaction in the Workplace}

We explore the relationship between reported job satisfaction and own wage, relative wage and average comparison group wage; allowing for asymmetry in these responses across genders. We find that the choice of relevant comparison group is affected by gender in Britain; men display behaviour characteristic of competitiveness whilst women do not.
\end{abstract}

JEL Classification: J3, J7, J28

Keywords: $\quad$ job satisfaction, earnings, gender, segregation, workplace

Corresponding author:

Karen Mumford

Department of Economics and Related Studies

University of York

Heslington

York YO10 5DD

United Kingdom

E-mail: karen.mumford@york.ac.uk 


\section{Introduction.}

A substantial and persistent earnings gap exists between male and female employees in Britain (see Table 1). Despite this sizable earnings gap, British women typically report higher levels of job satisfaction than do men.

Table 1. Employee earnings by gender, Britain 2004.

\begin{tabular}{lccc}
\hline & Male & Female & All \\
Average hourly wages & $£ 10.55$ & $£ 8.76$ & $£ 9.70$ \\
Average log hourly wages & 2.243 & 2.056 & 2.154 \\
Job satisfaction (index 0-6) & 3.318 & 3.606 & 3.453 \\
\hline
\end{tabular}

Source: WERS 2004.

This paper considers this apparent contradiction by asking whether the higher job satisfaction reported by female employees is due to their being less concerned by the level of co-worker wages.

Employees appear to have a good understanding of their wage relative to their fellow employees, male or female, (Hampton and Heywood, 1993). This is not to say that they care equally about the gap between their own wage and the salaries of all other employees. It has long been recognised that workers compare their wages to other workers they consider to be similar to themselves by custom (Mill, 1867:236; Phelps Brown, 1979:134). Recently, Card et al (2012) have shown that the response of an employee to their relative wage is perhaps not obvious a priori. Workers may care about the absolute size of the gap between their own wage and the comparison group (Phelps Brown, 1979:141). Or they may distinguish between an increase in their own wage and a reduction in the average wage in the comparison group (Easterlin, 1995:36-37). Furthermore, the behavioural responses are not clearly established in the literature. Card et al (2012) propose a comparison between two approaches as between a model of relative utility where an employee may be dissatisfied if their wage is lower than other workers (see also Zizzo and Oswald, 2001) and a model of co-worker wage as a signal of future wages (see also Clark et al, 2009). Employees may also react asymmetrically to co-worker wages depending on whether they are being paid relatively higher or lower than their comparison group (Duesenberry, 1949; Clark et al, 2009; Ferrer-i-Carbonell, 2005). 
This paper explores gender differences in the relationship between job satisfaction and relative wages amongst co-workers at the establishment level using linked employee and workplace data for Britain (WERS04). In particular, we address the possibility that that the relevant comparison group for individual workers is affected by gender.

\section{Data and methodology}

Following Clark and Senik (2010) we model job satisfaction as:

$$
S_{i}=S_{i}\left(W_{i}, W_{i}-\bar{W}_{i}, X_{i}, \ldots\right)
$$

Where $S_{i}$ is the job satisfaction of worker $i ; W_{i}$ is the wage of that worker; $\bar{W}_{i}$ is the average wage of their reference group and $X_{i}$ is a vector of observable employee and workplace characteristics correlated with job satisfaction.

The matched employee-workplace data used in this study are drawn from the British Workplace Employee Relations Survey 2004 (WERS04). WERS04 is a stratified random sample of workplaces with 5 or more employees; larger workplaces and some industries are over-represented. The data have been weighted throughout the paper to allow for the (stratified and clustered) survey design and thus represent the sampling population.

An aggregate measure of job satisfaction is calculated from six satisfaction measures for the individual employee. These measures are satisfaction with: influence over job; sense of achievement; scope for using own initiative; pay; job security; and work. In each case a binary measure is constructed for positive responses ('satisfied' or 'very satisfied') and then these binary measures are summed to form the aggregate scaled job satisfaction index measure taking values from 0 to 6 .

The employee characteristics included as determinants of job satisfaction are human capital related characteristics; demographic variables; and individual job characteristics. Workplace characteristics are physical and market conditions at the 
workplace including measures of high performance workplace practices (Lynch 2012). ${ }^{1}$

\section{Estimation and results}

The model for the scaled measure of job satisfaction is estimated using the ordered probit estimation method. It is assumed that the measured satisfaction reflects a latent welfare variable $\left(s^{*}\right)$ dependent on observed characteristics $(Z)$, which includes wage measures $W$ and control variables $X$, and an unobserved component $(\varepsilon)$ for employee $i$ in workplace $k$.

$$
S_{i k}^{*}=\beta Z_{i k}+\varepsilon_{i k}
$$

where $S_{i}=\lambda\left(s_{i k}^{*}\right)$ is a step function taking the category values 0-6 for job satisfaction according to $s_{i k}^{*}$ crossing a set of threshold levels.

We are interested in the impact of alternative measures of wage relativity on job satisfaction for different comparison groups: the workplace average wage; and separately, the workplace average male and female wages. We begin with the individuals' own wage relative to the comparison group average: the relative wage (= $\log \left(W_{i}\right)-\log ($ workplace comparison group average $)$ ) as part of the model for job satisfaction discussed above. The results for relative wages (Table 2) reveal that employees have higher job satisfaction levels if their relative wage is above the workplace comparison group average (see panel 1 of Table 2). This is true for both males and females, although male job satisfaction is substantially more sensitive (the effect is almost twice as large) to relative wages than is female job satisfaction.

Next, the restriction that the own and the relative wage measure have an equal and opposite effect is removed (see panel 2). These results suggest that employees' job satisfaction is raised by increases in their own wage level (especially for males) and is significantly affected by an average comparison wage measure in their workplace, be it the average of male or female or all employees. However, we find a significant asymmetric comparison effect, especially for women.

\footnotetext{
${ }^{1}$ Variable definitions and full results are provided in the Online Appendix.
} 
We examine the possibility that employees respond differently to their wage being relatively higher or relatively lower than the comparison group in panel 3. Both male and female employees show a positive relationship between reported job satisfaction and their own wage. These estimates are significant and positive, and are not significantly different between the two genders. However, the results show that male employees also gain satisfaction from having a wage rate higher than the average for the workplace comparison group: more so if the comparison group is the males in the workplace (but not significantly so). In contrast, the reported job satisfaction of female employees is not significantly related to the average wages of their workplace co-workers, male or female.

Our results contrast in terms of relative significance with those of Card et al (2012) who find that job satisfaction is lower for those below median earners whilst those above the median show no higher satisfaction. Card et al (2012) do not report any differences in responses between males and females. Clark et al (2009) examine job satisfaction in Danish workplaces and report results that contrast with ours and Card et al (2012). Whilst they find that higher wages raises job satisfaction for all workers, they find that below median wage workers have higher satisfaction if they work in higher wage establishments. They show a somewhat less significant effect for females than males.

Our results show a clearly significant difference in the response of males and females to earnings comparisons. This chimes with studies that examine broader income comparisons, for instance with friends and neighbours. Mayraz et al (2010) find substantial gender differences with income comparisons being much better predictors of well-being in males than in females.

\section{Conclusions}

Relative earnings is found to be an important determinant of job satisfaction for men; men care about their own wage level and the higher their wage is above the average wage (especially of other males) in their workplace. In contrast, women appear to be indifferent to the average wages of other men or women in their workplace. Their job 
satisfaction is sensitive only to their own wage level. Our evidence favours the relative utility model over a signalling explanation.

Our results suggest that the large earnings gap between men and women in British workplaces is not associated with lower job satisfaction levels for women whilst it is positively associated with higher job satisfaction levels for males. Consequently, it may be that little pressure is being exerted by either male or female employees to have the gender earnings gap reduced within their workplaces.

\section{Acknowledgments}

The author acknowledges the Department of Trade and Industry, the Advisory, Arbitration and Conciliation Service, the Economic and Social Research Council and the Policy Studies Institute as the originators of the 2004 Workplace Employment Relations Survey (WERS 2004) version 2 data.

\section{References}

Card, D. Mas, A. Moretti, E. and Saez, E. 2012. Inequality at work: the effect of peer salaries on job satisfaction, American Economic Review forthcoming.

Clark, A., Kristensen, N. and Westergard-Nielsen, N. 2009. Job satisfaction and coworkers wages: status or signal. Economic Journal 119, 430-447.

Clark, A. and Senik, C. 2010. Who compares to whom? The anatomy of income comparisons in Europe. Economic Journal 120; 573-594.

Duesenberry, J.S. 1949. Income, Saving and the Theory of Consumer Behavior Harvard University Press.

Easterlin, R.A. 1995. Will raising the incomes of all increase the happiness of all? Journal of Economic Behavior and Organization 27(1): 35-47.

Ferrer-i-Carbonell, A. 2005. Income and well-being: an empirical analysis of the comparison income effect. Journal of Public Economics 89: 997-1019.

Hampton, M. and Heywood, J. 1993. Do workers accurately perceive gender wage discrimination’ Industrial and Labor Relations Review 47: 36-49.

Lynch, L. 2012. The evolving nature of high performance workplace practices in the United States. In Advances in the Economic Analysis of Participatory and LaborManaged Firms. Edited by Bryson, A. (Emerald Books, London.)

Mayraz, G., Wagner, G., and Schupp, J. 2009. Life satisfaction and relative income perceptions and evidence. IZA DP 4390.

Mill, J.S. 1867. Principles of Political Economy. Routledge and Sons, London. 
Phelps Brown, H. 1979. The Inequality of Pay. Oxford University Press.

Zizzo, D. and Oswald, A. 2001. Are people willing to pay to reduce other's incomes? Annales d'Economie et Statistique 63: 39-65.

Table 2. Job satisfaction and wage relativity.

\begin{tabular}{|c|c|c|c|c|c|c|}
\hline & \multicolumn{2}{|c|}{ all } & \multicolumn{2}{|c|}{ males } & \multicolumn{2}{|c|}{ females } \\
\hline & coeff & s.error & coeff & s.error & coeff & s.error \\
\hline relative to average workplace wage & 0.258 & 0.032 & 0.387 & 0.047 & 0.187 & 0.043 \\
\hline relative to average male workplace wage & 0.246 & 0.032 & 0.359 & 0.047 & 0.191 & 0.041 \\
\hline relative to average female workplace wage & 0.222 & 0.034 & 0.326 & 0.051 & 0.167 & 0.042 \\
\hline own wage & 0.329 & 0.033 & 0.439 & 0.048 & 0.280 & 0.045 \\
\hline average workplace wage & 0.031 & 0.072 & -0.113 & 0.099 & 0.111 & 0.086 \\
\hline own wage & 0.336 & 0.033 & 0.431 & 0.048 & 0.295 & 0.045 \\
\hline average male workplace wage & -0.012 & 0.063 & -0.063 & 0.091 & -0.002 & 0.071 \\
\hline own wage & 0.325 & 0.033 & 0.424 & 0.048 & 0.279 & 0.045 \\
\hline average female workplace wage & 0.062 & 0.071 & -0.041 & 0.103 & 0.116 & 0.078 \\
\hline own wage & 0.341 & 0.074 & 0.315 & 0.098 & 0.396 & 0.091 \\
\hline above average workplace wage & 0.190 & 0.094 & 0.457 & 0.123 & -0.161 & 0.139 \\
\hline below average workplace wage & -0.115 & 0.080 & -0.070 & 0.114 & -0.097 & 0.093 \\
\hline own wage & 0.303 & 0.067 & 0.364 & 0.092 & 0.290 & 0.079 \\
\hline above average male workplace wage & 0.280 & 0.093 & 0.416 & 0.124 & 0.033 & 0.140 \\
\hline below average male workplace wage & -0.066 & 0.069 & -0.103 & 0.104 & -0.004 & 0.076 \\
\hline own wage & 0.377 & 0.075 & 0.389 & 0.106 & 0.397 & 0.085 \\
\hline above average female workplace wage & 0.092 & 0.097 & 0.275 & 0.133 & -0.132 & 0.121 \\
\hline below average female workplace wage & -0.149 & 0.078 & -0.156 & 0.121 & -0.111 & 0.087 \\
\hline number observations & & 17810 & & 8606 & & 9183 \\
\hline
\end{tabular}

Source: WERS 2004. The models include the full set of explanatory variables discussed above: individual characteristics; occupations; job characteristics; industry; workplace characteristics; regions; and measures of gender segregation at the workplace and the occupational level. (Full results are provided in the Online Appendix.) Italics significant at the $95 \%$ or bold $99 \%$ confidence level or above. 


\title{
Online Appendix for
}

\section{Peer salaries and employee satisfaction in the workplace.}

\author{
Karen Mumford ${ }^{1,2}$ and Peter N. Smith ${ }^{1}$ \\ ${ }^{1}$ Department of Economics \\ University of York \\ ${ }^{2}$ IZA, Institute for the Study of Labour.
}

June, 2012.

\section{Acknowledgments}

The author acknowledges the Department of Trade and Industry, the Advisory, Arbitration and Conciliation Service, the Economic and Social Research Council and the Policy Studies Institute as the originators of the 2004 Workplace Employment Relations Survey (WERS 2004) version 2 data.

Corresponding author: Prof. Karen Mumford, karen.mumford@york.ac.uk Department of Economics and Related Studies, University of York. Heslington York YO10 5DD, UK. 


\section{Appendix Table A1. Variable definitions.}

\author{
Variable name \\ job satisfaction index
}

employee measures;

log hourly pay

age

training

education measures;

other

none

minimal

cse25

cse1

gceae

gce2ae

degree

postgraduate

female

child 0-18

child 0-4

child 5-11

child 12-18

married

disabled

ethnic

fixed contract

hours

standard hours

overtime hours

part time

tenure

union

occupation categories;
managerial
professional
technical
clerical
craft
personal
sales
operative
unskilled

\section{Variable definition}

Index of six job satisfaction measures for the individual employee: satisfaction with influence over job; satisfaction with pay; satisfaction with sense of achievement; satisfaction with scope for using own initiative; satisfaction with job security; satisfaction with work itself.

The natural log of average hourly pay

Age

Days of employer provided training in previous year

Has other academic qualifications but doesn't have a listed recognised qualification

Doesn't have a recognised academic qualification

Education 'none' or 'other' above.

Has GCSE grades D-G; CSE grades 2-5 SCE; O grades D-; SCE Standard grades 4-7

Has GCSE grades A-C; GCE O-level passes; CSE grade 1 SCE; O grades A-C; or SCE

Standard 1-3

Has GCE A-level grades A-E; 1-2 SCE; Higher grades A-C, As levels

Has 2 or more GCE; A-levels grades A-E; 3 or more SCE; or Higher grades A-C

Has a first degree, eg BSc, BA, HND, HNC Ma at first degree level

Has a higher degree, eg MSc, MA, PGCE, PhD

Female

Has a dependent child aged below 18

Youngest dependent child aged 0-4

Youngest dependent child aged 5-11

Youngest dependent child aged 12-18

Married or living with a partner

Has a long term (>1 year) illness/disability

Employee considers they are white and black Caribbean; white and black African; white and Asian; any other mixed background; Indian; Pakistani; Bangladeshi; any other Asian background; Caribbean; African; any other black background; Chinese; or other ethnic group. Employed on a fixed term contract.

Usual hours worked per week (includes over time)

Usual hours worked per week minus over time

Usual overtime hours per Week

Working part time, if usual working hours is less than 30 per week

Years at this workplace

Employee is a current trade union member

Managerial

Professional

Technical

Clerical

Craft service

Personal service

Sales and customer services

Operative and assembly workers

Unskilled 


\begin{tabular}{|c|c|}
\hline Variable name & Variable definition \\
\hline \multicolumn{2}{|l|}{ industry categories; } \\
\hline manufacturing & manufacturing \\
\hline utilities & electricity, gas, and water supply \\
\hline construction & construction \\
\hline whole/retail & Wholesale and retail \\
\hline hotels & hotels and restaurants \\
\hline transport & transport and communication \\
\hline financial services & financial services \\
\hline other business & other business services \\
\hline public admin & public administration \\
\hline education & education \\
\hline health & health and social work \\
\hline other community & other community services \\
\hline \multicolumn{2}{|l|}{ workplace measures; } \\
\hline workplace age & Establishment age \\
\hline workplace size & Total number of employees at the workplace \\
\hline multi site & Firm has multiple UK work sites \\
\hline foreign owned & Foreign-controlled \\
\hline increasing market & Market for workplace main product or service is growing \\
\hline family friendly index & $\begin{array}{l}\text { Index of Six Family Friendly Policies: paternity leave; maternity leave; home working; job } \\
\text { sharing; child care; paid leave. }\end{array}$ \\
\hline paternity leave & If employees on paternity leave receives the normal, full rate of pay \\
\hline maternity leave & If employees on maternity leave receives the normal, full rate of pay \\
\hline home working & If employees can work at home \\
\hline job sharing & If a job sharing scheme exists in the workplace \\
\hline child care & If a workplace nursery or child care subsidy is available at the workplace \\
\hline employee interaction index & $\begin{array}{l}\text { Index of five employee-employer interaction measures at the workplace: employee has a lot } \\
\text { of discretion over work; quality circles exists; team working exists; employees consulted over } \\
\text { targets; employee briefing system exists }\end{array}$ \\
\hline IR index & $\begin{array}{l}\text { Index of three industrial relations measures at the workplace: union membership presence; } \\
\text { human resources representative; collective grievance procedure present }\end{array}$ \\
\hline equal opportunities & Workplace has a formal written equal opportunity policy \\
\hline relative female workplace & Percentage of the workplace employees who are female \\
\hline relative female occupation & Percentage of the occupation who are female \\
\hline \multicolumn{2}{|l|}{ Regions; } \\
\hline north east of England & north east of England \\
\hline north west of England & north west of England \\
\hline Yorkshire \& Humberside & Yorkshire \& the Humberside \\
\hline east midlands of England & east midlands of England \\
\hline west midlands of England & west midlands of England \\
\hline east of England & east of England \\
\hline London & London \\
\hline south east of England & south east of England \\
\hline south west of England & south west of England \\
\hline Scotland & Scotland \\
\hline Wales & Wales \\
\hline
\end{tabular}

Source: WERS 2004. 
Table A2. Summary statistics.

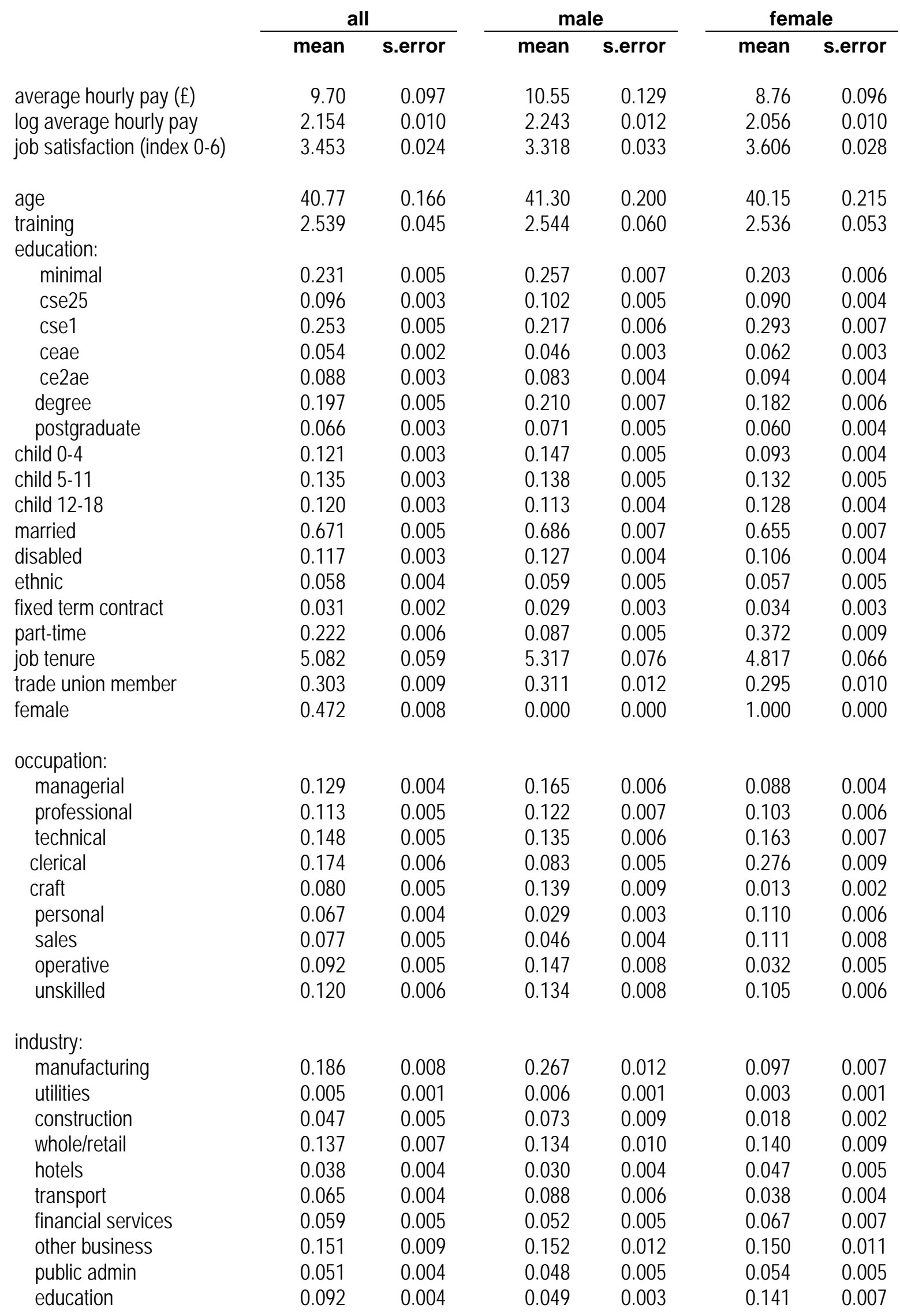




\begin{tabular}{lcccccc}
\hline & \multicolumn{2}{c}{ all } & \multicolumn{2}{c}{ male } & \multicolumn{2}{c}{ female } \\
& mean & s.error & mean & s.error & & s.ean \\
& & & & & & \\
health & 0.123 & 0.006 & 0.054 & 0.005 & 0.199 & 0.010 \\
$\quad$ other community & 0.046 & 0.005 & 0.047 & 0.006 & 0.045 & 0.005 \\
& & & & & & \\
workplace age & 44.53 & 1.833 & 45.59 & 2.153 & 43.36 & 1.943 \\
workplace size & 420.1 & 21.83 & 420.8 & 27.27 & 419.8 & 28.21 \\
multi site & 0.747 & 0.014 & 0.729 & 0.017 & 0.767 & 0.014 \\
foreign owned & 0.153 & 0.012 & 0.194 & 0.016 & 0.108 & 0.011 \\
increasing market & 0.331 & 0.015 & 0.344 & 0.018 & 0.316 & 0.016 \\
family friendly index & 3.071 & 0.044 & 2.924 & 0.055 & 3.234 & 0.048 \\
IR index & 2.608 & 0.035 & 2.565 & 0.043 & 2.657 & 0.039 \\
HP practices & 1.190 & 0.027 & 1.178 & 0.032 & 1.204 & 0.030 \\
equal opportunity policy & 0.856 & 0.010 & 0.839 & 0.013 & 0.875 & 0.011 \\
relative female workplace & 49.15 & 0.800 & 33.37 & 0.787 & 66.75 & 0.609 \\
relative female occupation & 51.01 & 0.394 & 41.70 & 0.481 & 61.39 & 0.384 \\
& & & & & & \\
regions: & & & & & & \\
north east of England & 0.042 & 0.007 & 0.045 & 0.009 & 0.038 & 0.006 \\
$\quad$ north west of England & 0.146 & 0.012 & 0.150 & 0.014 & 0.141 & 0.013 \\
Yorkshire \& Humberside & 0.090 & 0.010 & 0.090 & 0.012 & 0.091 & 0.011 \\
$\quad$ east midlands of England & 0.094 & 0.009 & 0.091 & 0.011 & 0.097 & 0.011 \\
west midlands of England & 0.090 & 0.009 & 0.093 & 0.011 & 0.087 & 0.010 \\
east of England & 0.106 & 0.009 & 0.100 & 0.011 & 0.112 & 0.011 \\
London & 0.131 & 0.011 & 0.128 & 0.013 & 0.133 & 0.013 \\
south east of England & 0.079 & 0.008 & 0.074 & 0.009 & 0.086 & 0.010 \\
south west of England & 0.118 & 0.011 & 0.119 & 0.014 & 0.117 & 0.012 \\
Scotland & 0.037 & 0.005 & 0.039 & 0.006 & 0.035 & 0.006 \\
Wales & 3.453 & 0.024 & 3.318 & 0.033 & 3.606 & 0.028 \\
& & & & & & \\
number of observations & & 17810 & & 8606 & & 9183 \\
& & & & & & \\
\hline \hline
\end{tabular}

Source: WERS 2004. 
Table A3. Job satisfaction, ordered probits.

\begin{tabular}{|c|c|c|c|c|c|c|c|c|c|}
\hline & al & & & male & & & femal & & \\
\hline & coeff & s.error & z val & coeff & s.error & z val & coeff & s.error & z val \\
\hline age & -0.029 & 0.007 & $\star \star \star ~$ & -0.029 & 0.009 & $\star \star \star ~$ & -0.028 & 0.009 & $\star \star \star ~$ \\
\hline age squared & 0.431 & 0.079 & $\star \star \star ~$ & 0.429 & 0.106 & $\star \star \star ~$ & 0.409 & 0.112 & 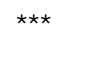 \\
\hline training & 0.072 & 0.004 & $\star \star \star ~$ & 0.077 & 0.005 & $\star \star \star ~$ & 0.066 & 0.005 & 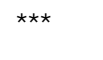 \\
\hline education (education & al omittec & & & & & & & & \\
\hline $\operatorname{cse} 25$ & -0.066 & 0.040 & & -0.140 & 0.055 & ** & 0.027 & 0.057 & \\
\hline cse1 & -0.168 & 0.030 & *** & -0.227 & 0.043 & $\star \star \star$ & -0.103 & 0.043 & $\star \star$ \\
\hline ceae & -0.229 & 0.045 & $\star \star \star ~$ & -0.230 & 0.070 & $\star \star \star ~$ & -0.216 & 0.062 & $\star \star \star ~$ \\
\hline ce2ae & -0.189 & 0.044 & $\star \star \star ~$ & -0.231 & 0.064 & $\star \star \star ~$ & -0.155 & 0.057 & 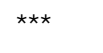 \\
\hline degree & -0.232 & 0.039 & 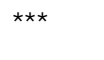 & -0.260 & 0.052 & *** & -0.187 & 0.053 & $* \star \star$ \\
\hline postgraduate & -0.234 & 0.048 & $\star \star \star ~$ & -0.215 & 0.067 & $\star \star \star ~$ & -0.271 & 0.065 & 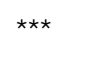 \\
\hline child 0-4 & 0.013 & 0.034 & & -0.009 & 0.043 & & 0.038 & 0.053 & \\
\hline child 5-11 & 0.098 & 0.032 & $\star \star \star ~$ & 0.123 & 0.044 & $\star \star \star ~$ & 0.064 & 0.046 & \\
\hline child 12-18 & 0.052 & 0.030 & & 0.026 & 0.046 & & 0.072 & 0.041 & \\
\hline married & 0.105 & 0.024 & $\star \star \star *$ & 0.159 & 0.035 & *** & 0.054 & 0.030 & \\
\hline disabled & -0.188 & 0.029 & $\star \star \star ~$ & -0.199 & 0.039 & $\star \star \star ~$ & -0.192 & 0.041 & 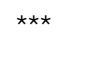 \\
\hline ethnic & -0.022 & 0.043 & & 0.078 & 0.060 & & -0.126 & 0.065 & ** \\
\hline fixed contract & -0.151 & 0.052 & *** & -0.115 & 0.074 & & -0.167 & 0.075 & $\star *$ \\
\hline part-time & 0.138 & 0.028 & *** & 0.144 & 0.054 & *** & 0.128 & 0.033 & 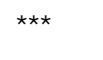 \\
\hline tenure & 0.002 & 0.003 & & -0.004 & 0.005 & & 0.009 & 0.004 & $\star \star$ \\
\hline union & -0.132 & 0.026 & $\star \star \star *$ & -0.132 & 0.036 & $\star \star \star$ & -0.114 & 0.034 & $\star \star \star ~$ \\
\hline occupation (craft/pers & ervices 0 & iitted) & & & & & & & \\
\hline managerial & 0.319 & 0.044 & *** & 0.363 & 0.055 & $\star \star \star ~$ & 0.198 & 0.086 & ** \\
\hline professional & 0.178 & 0.044 & $\star \star \star ~$ & 0.129 & 0.066 & & 0.256 & 0.070 & $\star * \star$ \\
\hline technical & 0.105 & 0.039 & $\star \star \star ~$ & 0.153 & 0.067 & ** & 0.045 & 0.055 & \\
\hline clerical & 0.051 & 0.045 & & 0.077 & 0.090 & & 0.019 & 0.050 & \\
\hline sales & -0.064 & 0.061 & & -0.033 & 0.098 & & -0.076 & 0.072 & \\
\hline operative & -0.077 & 0.052 & & -0.062 & 0.055 & & -0.149 & 0.130 & \\
\hline unskilled & 0.004 & 0.047 & & -0.016 & 0.067 & & 0.056 & 0.075 & \\
\hline industry (manufacturi & ted) & & & & & & & & \\
\hline utilities & 0.033 & 0.111 & & -0.004 & 0.130 & & 0.065 & 0.230 & \\
\hline construction & 0.245 & 0.062 & $\star \star \star *$ & 0.220 & 0.070 & $\star \star \star$ & 0.297 & 0.136 & ** \\
\hline whole/retail & 0.207 & 0.053 & $\star \star \star$ & 0.235 & 0.062 & $\star \star \star$ & 0.166 & 0.077 & $\star \star$ \\
\hline hotels & 0.171 & 0.073 & ** & 0.245 & 0.109 & ** & 0.061 & 0.092 & \\
\hline transport & -0.013 & 0.065 & & -0.059 & 0.078 & & 0.072 & 0.088 & \\
\hline financial services & -0.078 & 0.067 & & -0.112 & 0.084 & & -0.077 & 0.082 & \\
\hline
\end{tabular}




\begin{tabular}{|c|c|c|c|c|c|c|c|c|c|}
\hline & \multicolumn{2}{|c|}{ all } & \multirow[b]{2}{*}{ z val } & \multicolumn{2}{|c|}{ males } & \multirow[b]{2}{*}{ z val } & \multicolumn{2}{|c|}{ females } & \multirow[b]{2}{*}{ z va } \\
\hline & coeff & s.error & & coeff & s.error & & coeff & s.error & \\
\hline other business & 0.089 & 0.052 & & 0.088 & 0.063 & & 0.091 & 0.074 & \\
\hline public admin & 0.063 & 0.066 & & -0.005 & 0.075 & & 0.109 & 0.095 & \\
\hline education & 0.231 & 0.057 & 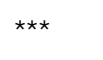 & 0.151 & 0.081 & $\star *$ & 0.267 & 0.080 & $\star \star \star$ \\
\hline health & 0.251 & 0.057 & $\star \star *$ & 0.136 & 0.097 & & 0.336 & 0.076 & $\star \star \star *$ \\
\hline other community & 0.172 & 0.068 & 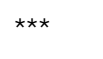 & 0.208 & 0.077 & 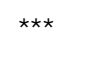 & 0.128 & 0.095 & \\
\hline workplace age & 0.000 & 0.000 & & 0.000 & 0.000 & & 0.000 & 0.000 & \\
\hline workplace size & 0.000 & 0.000 & & 0.000 & 0.000 & & 0.000 & 0.000 & \\
\hline multi site & -0.110 & 0.034 & 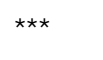 & -0.146 & 0.047 & $\star \star \star ~$ & -0.077 & 0.040 & ** \\
\hline foreign owned & -0.027 & 0.039 & & -0.080 & 0.047 & * & 0.075 & 0.055 & \\
\hline increasing market & 0.054 & 0.028 & ** & 0.049 & 0.038 & & 0.064 & 0.034 & ** \\
\hline family friendly index & -0.016 & 0.010 & & -0.006 & 0.013 & & -0.028 & 0.012 & ** \\
\hline IR index & -0.011 & 0.012 & & 0.001 & 0.015 & & -0.021 & 0.015 & \\
\hline employee interaction & -0.022 & 0.015 & & -0.019 & 0.020 & & -0.020 & 0.020 & \\
\hline equal opp & -0.114 & 0.047 & ** & -0.128 & 0.061 & ** & -0.110 & 0.057 & ** \\
\hline rel female workplace & 0.000 & 0.001 & & 0.001 & 0.001 & & -0.001 & 0.001 & \\
\hline rel female occupation & 0.000 & 0.001 & & -0.001 & 0.001 & & -0.001 & 0.002 & \\
\hline \multicolumn{10}{|c|}{ Region (east Midlands omitted): } \\
\hline north east of England & -0.086 & 0.089 & & 0.053 & 0.102 & & -0.246 & 0.113 & ** \\
\hline north west of England & -0.064 & 0.059 & & -0.048 & 0.072 & & -0.076 & 0.072 & \\
\hline Yorkshire \& Humber & -0.043 & 0.066 & & 0.045 & 0.084 & & -0.127 & 0.077 & \\
\hline west Midland England & -0.072 & 0.063 & & -0.085 & 0.084 & & -0.069 & 0.073 & \\
\hline east of England & -0.096 & 0.070 & & -0.032 & 0.097 & & -0.162 & 0.079 & $\star *$ \\
\hline London & -0.060 & 0.067 & & 0.035 & 0.086 & & -0.159 & 0.080 & ** \\
\hline south east of England & -0.081 & 0.059 & & -0.028 & 0.073 & & -0.146 & 0.072 & $* *$ \\
\hline south west of England & -0.033 & 0.065 & & 0.034 & 0.086 & & -0.106 & 0.078 & \\
\hline Scotland & -0.093 & 0.061 & & -0.032 & 0.078 & & -0.174 & 0.075 & ** \\
\hline Wales & -0.020 & 0.071 & & 0.063 & 0.094 & & -0.131 & 0.100 & \\
\hline female & 0.117 & 0.024 & $\star \star \star ~$ & & & & & & \\
\hline \multirow[t]{2}{*}{ number observations } & & 17810 & & & 8606 & & & 9183 & \\
\hline & $9,1294)$ & 19.090 & & $F(58,1182)$ & 12.830 & & $F(58,1209)$ & 9.790 & \\
\hline
\end{tabular}

Source: WERS 2004. ${ }^{* *}$ Significant at the $95 \%$ or $* * * 99 \%$ confidence level or above. 